\title{
Acumulación estacional de biomasa aérea de alfalfa Var. Oaxaca criolla (Medicago sativa L.)
}

\section{Seasonal aerial biomass accumulation of native lucerne (Medicago sativa L.)}

\author{
Fausto J avier Montes Cruza, Rigoberto Castro Riveraa, Gisela Aguilar Benítezb, \\ Sadoth Sandoval Torresa, María Myrna Solís Obac
}

\begin{abstract}
RESUMEN
El conocimiento de las dinámicas de acumulación de biomasa de una especie forrajera en las diferentes épocas del año, es una metodología útil para una mejor planeación y aprovechamiento del cultivo para obtener los mayores rendimientos y material vegetal de buena calidad nutritiva. El objetivo del presente estudio fue determinar curvas de acumulación de forraje, tasa de crecimiento, altura de forraje, relación hoja:tallo y composición botánica, en una pradera de alfalfa de tres años de establecida. Se utilizó un diseño experimental de bloques completos al azar con siete tratamientos y cuatro repeticiones. El mayor rendimiento de materia seca se registró $(P<0.01)$ a los 49 días de rebrote en primavera, verano y otoño (2,794, 2,680 y 2,116 Kg MS ha-1, respectivamente), y a los 42 días en invierno

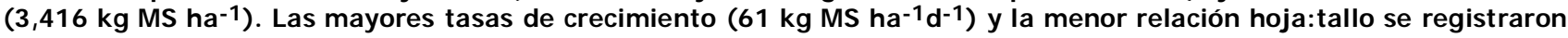
en el invierno. La mayor presencia de otros pastos y malezas fue en primavera y verano. Se concluye realizar cortes cada 35 a 40 días en invierno y otoño, mientras que en primavera y verano cada 30 a 35 días, y no cada 40 días independientemente de la estación del año, como se hace comúnmente en la región.
\end{abstract}

PALABRAS CLAVE: Dinámicas de crecimiento, Rendimiento de forraje, Alfalfa criolla.

\begin{abstract}
Knowledge of dynamics herbage yield at different times of the year is a useful methodology for improving pasture management and optimize the performance and quality plant. The aim of the study was to determine the herbage accumulation curves, average growth rate, forage height, leaf:stem ratio, and botanical composition in a lucerne pastureland of $3 \mathrm{yr}$ of established. The experimental design was a randomized complete block design with four replicates. The highest dry matter yield was recorded $(P<0.01)$ at 49 regrowth days in spring, summer and autumn $(2,794,2,680$ and 2,116 $\mathrm{kg} \mathrm{DM} \mathrm{ha-1}$, respectively), and $42 \mathrm{~d}$ in winter (3,416 $\mathrm{Kg} \mathrm{DM} \mathrm{ha-1)}$. The highest growth rates (61 $\mathrm{kg} \mathrm{DM} \mathrm{ha}^{-1} \mathrm{~d}^{-1}$ ) and the lower leaf:stem ratio was recorded in the winter. The increased presence of other grasses and weeds was in spring and summer. It concludes to make defoliations every 35 to $40 \mathrm{~d}$ in winter and autumn, whereas in spring and summer every 30 to $35 \mathrm{~d}$, not every $\mathbf{4 0}$ d regardless of the season, as it is commonly done in the region.
\end{abstract}

KEY WORDS: Growth dynamics, Yield, Native lucerne.

La alfalfa (Medicago sativa L.) es la leguminosa más utilizada en la alimentación del ganado a nivel mundial, su importancia radica en el rendimiento y valor nutritivo(1). Su fenología y tasa de regeneración permite realizar cosechas repetidas(2). En el estado de Oaxaca, el
Lucerne (Medicago sativa $L$.) is the legume most used for livestock feeding around the world, its importance lies in its yield and nutritional value ${ }^{(1)}$. Its phenology and regrowth rate allows repeated crops(2). In the State of Oaxaca, the use is either green or marketed in bulk(3).

Recibido el 1 de junio de 2015. Aceptado el 10 de agosto de 2015.

a Instituto Politécnico Nacional, CIIDIR, Unidad Oaxaca. Hornos 1003, Sta. Cruz Xoxocotlán, Oaxaca, México. Tel. 019515170610 Ext. 82754. rcastror@ipn.mx, correspondencia al segundo autor.

b Instituto de Investigación de Zonas Desérticas. Universidad Autónoma de San Luís Potosí. México.

c Instituto Politécnico Nacional, ClBA Tlaxcala. México. 
aprovechamiento es en verde o bien comercializada en manojos(3).

El rebrote del forraje es considerado como el tiempo que le toma a la planta recuperar la biomasa removida después de una defoliación, de ahí la importancia de conocer la fenología de la planta al acumular su biomasa entre una cosecha y la siguiente(4). Con el avance de la madurez, los cambios físicos y químicos del forraje provocan disminución en la digestibilidad y aumenta el rendimiento, reduciéndose la relación hoja:tallo, la cual está ligada con la calidad, ya que las hojas y tallos contienen diferentes concentraciones de proteína y fibra $(5,6)$; así mismo, el rebrote depende de la morfogénesis de la planta para la producción de hojas(7).

Un esquema de manejo basado en un calendario de días de descanso o por el estadio de desarrollo del cultivo, es una buena opción para el manejo, llegando a la recomendación generalizada de cosechar cuando exista un $10 \%$ de floración o se presente la hoja bandera, en leguminosas y gramíneas respectivamente. Sin embargo, una recomendación no puede ser universalmente aplicable(8,9). Por lo anterior, es necesario conocer la dinámica de acumulación de biomasa después de la defoliación, la cual varía por factores ambientales. De esta forma, el conocimiento de los cambios estacionales en el rendimiento, permite determinar la mejor frecuencia de cosecha, para obtener la mayor producción de forraje de alta calidad por superficie(10,11).

Al respecto, en el Estado de México un estudio(12) reportó que la alfalfa presentó un rendimiento de forraje más alto en mayo. Asimismo(13), en Oaxaca, al evaluar cinco variedades de alfalfa encontraron que el mayor rendimiento de MS fue en julio y agosto, con un promedio de 2.82 t MS ha-1, y se presentó el siguiente orden descendente: verano $31 \%$ $>$ primavera $27 \%>$ otoño $22 \%>$ invierno $20 \%$. Otra investigación(14) en Oaxaca reportó que la alfalfa cultivada en invernadero y con
The forage regrowth is considered as the time it takes the plant to recover the removed biomass after a defoliation, hence the importance of knowing the plant phenology to accumulate their biomass between $\operatorname{crops}(4)$. With the advance of the maturity, physical and chemical changes of the forage cause a decreased digestibility and increased yield, reducing the leaf:stem ratio, which is linked with quality, since the leaves and stems contain different concentrations of protein and fiber $(5,6)$; likewise, the regrowth depends on the morphogenesis of the plant for the production of leaves(7).

A scheme of management based on a calendar resting days or by the stage of development of the crop, is a good choice for handling, reaching the widespread recommendation of harvest when there is a $10 \%$ flowering or the presence of the leave flag, in legumes and grasses respectively; however, a recommendation cannot be universally applicable $(8,9)$. Therefore, it is necessary to know the dynamics of biomass accumulation after defoliation, which varies by environmental factors. In this way, knowledge of seasonal changes in yield, allows to determine the best harvest frequency, to get more high quality forage production by area $(10,11)$.

In this regard in the State of Mexico, a study(12) reported that lucerne presented a higher forage yield on May. Also(13), in Oaxaca, assessing five lucerne varieties found that the greater dry matter (DM) yield was on July and August, with an average of $2.82 \mathrm{t}$ DM ha-1, and presented the following descending order: summer $31 \%>$ spring $27 \%>$ fall $22 \%>$ winter $20 \%$. Another investigation(14) in Oaxaca reported that 14 varieties of lucerne grown in greenhouse and with fertigation, does not register variations in DM yield; however, the highest yield and height were recorded on April and May, so the temperature is closely related to the forage performance( 15$)$.

In several research studies has been shown the importance of regrowth and the effect of the 
fertirriego, no registra variaciones de 14 variedades en el rendimiento de MS; sin embargo, el mayor rendimiento y altura se registraron en los meses de abril y mayo, por lo que la temperatura está estrechamente relacionada con el rendimiento de forraje(15).

En varias investigaciones se ha demostrado la importancia del rebrote y el efecto de la frecuencia de cosecha en la persistencia, y el efecto ambiental sobre el rendimiento, lo que permite un manejo más eficiente de producción animal-vegetal por hectárea(16). En relación a lo anterior, en un estudio hecho en Oaxaca(10) registraron que en primavera, la alfalfa variedad Valenciana, alcanzó el máximo rendimiento a la sexta semana ( $4.7 \mathrm{t} \mathrm{MS} \mathrm{ha-}^{-1}$ ), mientras que la variedad Oaxaca (alfalfa criolla) los registró a la séptima semana (4.1 t MS ha-1), concluyendo que el momento óptimo de corte varió con la estación del año.

La calidad, rendimiento, persistencia y longevidad de la pradera depende del manejo estacional de la frecuencia de defoliación, por lo que definir el calendario de cortes con base en el rebrote del cultivo en cada estación es de suma importancia(13). Sin embargo, en los valles centrales de Oaxaca, la alfalfa se cosecha cada 40 días independientemente de la estación del año, lo que provoca cambios en la composición morfológica y bromatológica de la alfalfa. Es por ello que el objetivo del presente trabajo fue evaluar las dinámicas de crecimiento estacional en una pradera de alfalfa Var. Oaxaca o criolla, para determinar los momentos óptimos de cosecha por época para obtener el mayor rendimiento y calidad del forraje.

El estudio se realizó en una pradera de alfalfa Var. Oaxaca criolla (Medicago sativa L.) de tres años de establecida durante un año de evaluación (febrero 2011-enero 2013), ubicada en la comunidad de la Villa de Zaachila, Oaxaca, localizada a 160 56' 38.58" N y 96o 44' 12.61" O, a 1,509 msnm. El clima es templado subhúmedo $C(w)$, con lluvias en verano, con temperatura promedio anual de $17.5{ }^{\circ} \mathrm{C}$, y precipitación harvest frequency in the persistence, and the environmental effect on yield, which allows for more efficient handling of animal-vegetal production per hectare(16). In a study conducted in Oaxaca(10) recorded that in spring, lucerne variety Valencia, reached its maximum performance at the 6th wk (4.7 $\left.\mathrm{t} \mathrm{DM} \mathrm{ha}^{-1}\right)$, while the variety Oaxaca (creole lucerne) recorded it at 7th wk (4.1 t DM ha-1), concluding that the optimum time of cutting varied with the season of the year.

The quality, yield, persistence and longevity of the pasture depends on seasonal frequency of defoliation management, so defining the cuts calendar based on the re-emergence of the crop in each season is of paramount importance(13). However, in the central valleys of Oaxaca, lucerne is harvested every $40 \mathrm{~d}$ regardless of the season of the year, causing changes in its morphological and biochemistry composition. Therefore, the objective of the present study was to evaluate the dynamics of seasonal growth in a pastureland of lucerne Var. Oaxaca or Creole, to determine the optimum time to harvest by season, to get the highest yield and forage quality.

The study was conducted in a meadow of lucerne Var. Oaxaca creole (Medicago sativa L.) of $3 \mathrm{yr}$ of established during a year of assessment (February 2011 - January 2013), located in the community of the Villa de Zaachila, Oaxaca, at $16^{\circ} 56^{\prime} 38.58^{\prime \prime} \mathrm{N}$ and $96^{\circ} 44^{\prime} 12.61^{\prime \prime} \mathrm{W}$, at an altitude of $1,509 \mathrm{~m}$. The climate is temperate subhumid $C(w)$, with rains in summer, with an average annual temperature of $17.5{ }^{\circ} \mathrm{C}$, and average rainfall of $730 \mathrm{~mm}$. The type of soil is shallow, dark grey, with horizon A Malic acid, horizon B argillic, clayey texture, strong adhesiveness and plasticity, slightly $\mathrm{pH}$ alkaline, of medium fertility, classified as a Foazen livic(17).

For standardization, lucerne was cut at a height of $5 \mathrm{~cm}$ at the beginning of the experiment. The blocks were delimited based on the ground slope and established 28 experimental units of 
promedio de $730 \mathrm{~mm}$. El tipo de suelo es poco profundo, de color gris oscuro, con horizonte $\mathrm{A}$ málico, horizonte $B$ argilico, de textura arcillosa, con adhesividad y plasticidad fuerte, $\mathrm{pH}$ ligeramente alcalino, de fertilidad media, clasificado como Foazen livico(17).

Al inicio del experimento se realizó un corte de uniformización a una altura de $5 \mathrm{~cm}$. Se delimitaron los bloques con base a la pendiente del terreno y se establecieron 28 unidades experimentales de $5 \times 2 \mathrm{~m}$, mediante un diseño experimental de bloques al azar con siete tratamientos (semana de corte) y cuatro repeticiones. La pradera no se fertilizó y en la época de estiaje (octubre a mayo) se proporcionaron riegos cada dos semanas a capacidad de campo.

El rendimiento de forraje se midió con un cuadro de acero de $0.25 \mathrm{~m}^{2}$ por repetición(15), aleatoriamente se seleccionó el lugar de la muestra, en el cual, se cortó todo el forraje contenido dentro de éste a una altura de $5 \mathrm{~cm}$; el material vegetal cosechado se depositó en bolsas de papel previamente marcadas con el número de tratamiento y la repetición correspondiente, se lavó y se pesó en fresco; posteriormente se secó en un horno de microondas hasta un peso constante para obtener el valor de materia seca(18).

Se registró la altura de forraje antes de cada corte con una regla graduada de $1 \mathrm{~m}$ de longitud y una precisión de $0.5 \mathrm{~cm}$. Se efectuaron diez mediciones dentro de cada tratamiento, en plantas elegidas el azar, con la regla colocada completamente vertical desde la base de la planta hasta la hoja superior más joven $(19,20)$.

El forraje cosechado en cada unidad experimental, se mezcló para homogenizar la muestra, posteriormente se tomó una submuestra de aproximadamente $20 \%$ del forraje y las plantas se clasificaron por especie, material muerto, otros pastos y maleza; posteriormente se separó en sus componentes morfológicos (tallos, hojas, inflorescencia y
$5 \times 2 \mathrm{~m}$, using a randomized complete block design with seven treatments (week of cutting) and four replications. The pasture was not fertilized and in the dry season (October to May) irrigation was provided every 2 wk to field capacity.

Forage yield was measured with a steel frame of $0.25 \mathrm{~m}^{2}$ per replicate $(15)$; in the randomly selected sample place, all the fodder contained within this place was cut to a height of $5 \mathrm{~cm}$; the harvested plant material was deposited in paper bags previously marked with the number of treatment and the corresponding repetition, it was washed and weighed fresh, then dried in a microwave oven until constant weight to obtain the dry matter value(18).

The forage height was recorded before each cut with a graduated ruler $1 \mathrm{~m}$ length and a precision of $0.5 \mathrm{~cm}$. There were ten measurements within each treatment, plants chosen at random, with the settled rule completely vertical from the base of the plant to the youngest higher leaf $(19,20)$.

Forage harvested in each experimental unit was mixed to homogenize the sample and subsequently took a sub-sample of approximately $20 \%$ of the forage and plants were classified by species, dead material, other grasses and weeds; it was separated into its morphological components (stems, leaves, inflorescence and dead material); each component weighted in fresh and recorded their weight in dry basis(1).

The growth rate (GR) was calculated with data of dry matter yield through the following formula: $G R=H F / t$. Where $H F=$ harvested forage ( $k g$ DM ha- ${ }^{-1}$, and $t=$ days between a cut and the next.

The leaf:stem ratio was obtained by dividing the morphological component leaf yield between the component stem yield.

Monthly data average temperature (maximum, average and minimum) weather and 
material muerto) y se pesó cada componente en fresco y se registró su peso en base seca(1).

La tasa de crecimiento (TC) se calculó con los datos de rendimiento de materia seca por corte mediante la siguiente fórmula: $\mathrm{TC}=\mathrm{FC} / \mathrm{t}$. Donde $\mathrm{FC}=$ forraje cosechado $\left(\mathrm{kg} \mathrm{MS} \mathrm{ha}^{-1}\right), \mathrm{y} \mathrm{t}=$ días transcurridos entre un corte y el siguiente.

La relación hoja:tallo se obtuvo dividiendo el rendimiento por corte del componente morfológico hoja entre el rendimiento por corte del tallo.

Los datos mensuales de temperatura promedio mensual a la intemperie (máxima, media y mínima) y precipitación durante el periodo de estudio se obtuvieron de la estación meteorológica del aeropuerto Benito Juárez de la ciudad de Oaxaca, ubicada a $13 \mathrm{~km}$ del área de estudio.

Los valores agrupados se graficaron mediante el software estadístico SigmaPlot V.12(21) y se analizaron con el procedimiento PROC MIXED de SAS(22). Cuando no se cumplió el supuesto de normalidad de las variables, fueron transformadas, lo cual se realizó de acuerdo a las sugerencias de SAS. Para seleccionar la matriz de varianza y covarianza se utilizó el criterio de Akaike(23), con lo que se determinaron los efectos de las fuentes de variación (días de rebrote $7,14,21,28,35,42$, 49), época del año (primavera, verano, otoño e invierno), las cuales se consideraron como efectos fijos, y el efecto de bloques fue considerado como aleatorio(24). Las medias de tratamientos se estimaron utilizando LSMEANS y la comparación entre ellas se realizó por medio de la probabilidad de la diferencia (PDIFF), basado en la prueba de " $\mathrm{t}$ " de "Student" a un nivel de significancia del $5 \%$.

Para la regresión lineal entre la altura de la pradera y rendimiento de forraje, el registro de altura se realizó justo antes de hacer el muestreo del forraje. Se obtuvieron las ecuaciones de regresión lineal, y los intervalos de confianza al $95 \%$ y la predicción del rendimiento por época precipitation during the study period were obtained from the meteorological station of the airport Benito Juárez from the city of Oaxaca, located $13 \mathrm{~km}$ from the study area.

The grouped values were graphed using the statistical software SigmaPlot vol.12(21) and analyzed with the PROC MIXED procedure of SAS(22). When the assumption of normality of variables was not fulfilled, they were transformed according to the suggestions of SAS. The Akaike criterion was used to select the variance and covariance matrix(23), with what the effects of the sources of variation were determined: days of regrowth $(7,14,21,28,35,42,49)$, time of the year (spring, summer, autumn and winter), that were considered as fixed effects, and the effect of blocks considered as random(24). Treatments means were estimated using LSMEANS and comparison among them was carried out by the probability of the difference (PDIFF), based on the " $\mathrm{t}$ " test of "Student" to a level of significance of $5 \%$.

For the linear regression between the height of the pasture and forage yield, the height was performed just prior to the sampling of the forage. The equations of linear regression, and $95 \%$ confidence intervals and prediction of performance for time of the year, were obtained by the wizard regression module of the SigmaPlot V.12 software using a polynomial linear model(21).

The greatest dry matter yield $(P<0.01)$ was recorded in winter at $14 \mathrm{~d}$ compared with yields in spring, summer and fall, with lower yields in the fall (Figure 1A). Table 1 shows that all seasons showed a gradual increase in forage accumulation, reaching greater yields at $49 \mathrm{~d}$ in spring, summer and autumn with 2,794, 2,680 and 2,116 kg DM ha-1, respectively, while in winter it was at $42 \mathrm{~d}(3,416 \mathrm{~kg})$. Taking into account the maximum performance obtained in each of the seasons of the year, the winter exceeded on 22, 27 and $61 \%$, to spring, summer and autumn, respectively. In particular in spring there were no differences $(P>0.05)$ in the yield among d 35, 42 and 49 of regrowth. 
del año, utilizando el módulo wizard regression del Software SigmaPlot V.12 mediante un modelo polinomial lineal(21).

El mayor rendimiento de materia seca $(P<0.01)$ se registró en la época de invierno a partir de los 14 días en comparación con los rendimientos en primavera, verano y otoño, observándose los menores rendimientos en este último (Figura 1A). En el Cuadro 1, se observa que en todas las estaciones se registró un incremento progresivo en la acumulación de forraje, alcanzándose los mayores rendimientos a los 49 días en primavera, verano y otoño con 2,794, 2,680 y $2,116 \mathrm{~kg}$ MS ha-1, respectivamente, mientras que en invierno fue a los 42 días $(3,416 \mathrm{~kg} \mathrm{MS} \mathrm{ha-1)}$. Tomando en cuenta el rendimiento máximo obtenido en cada una de las épocas del año, el invierno superó en un 22, 27 y $61 \%$, a la primavera, verano y otoño, respectivamente. En particular en primavera no se observaron diferencias $(P>0.05)$ en el rendimiento entre los días 35,42 , y 49 días de rebrote.

Los resultados obtenidos difieren con lo reportado en otros trabajos $(1,25)$, donde concluyen que en alfalfa el mayor rendimiento estacional en Montecillo, Estado de México, se observó en verano; y coinciden parcialmente a lo informado(10) en un estudio en la misma variedad de alfalfa, y reportaron que la mayor acumulación de materia seca fue a los 49 días en primavera, pero no coinciden a lo reportado en verano, otoño e invierno, donde la mayor acumulación de biomasa se registró en los días 28,35 y 42 , respectivamente.

Las diferencias en los resultados, pueden deberse a que en el invierno se presentaron condiciones ambientales óptimas para el crecimiento de la alfalfa, ya que durante esos meses la temperatura promedio fluctuó entre 19 y $21{ }^{\circ} \mathrm{C}$, mientras que en otros estudios la presencia de heladas afectó la acumulación neta de alfalfa $(1,12,16)$. De acuerdo a lo reportado en la literatura(26), la temperatura óptima de crecimiento de la alfalfa es de 15 y $25{ }^{\circ} \mathrm{C}$
These results differ with those reported elsewhere $(1,25)$, which concluded that the best seasonal lucerne yield in Montecillo, State of Mexico, was observed in summer; and agrees partially to reports with the same lucerne variety $(10)$, which mention that the higher dry matter accumulation was at $49 \mathrm{~d}$ in spring, but do not agree to what was reported in summer, autumn and winter, where higher biomass

Figura 1. Rendimiento de materia seca $(A)$, relación hoja:tallo (B), tasa de crecimiento (C) y altura de la pradera (D). En ciclos de crecimiento de siete semanas

Figure 1. Dry matter yield (A), Leaf:stem ratio (B), Growth rate $(C)$, Forage height $(D)$. In seven weeks growth cycles

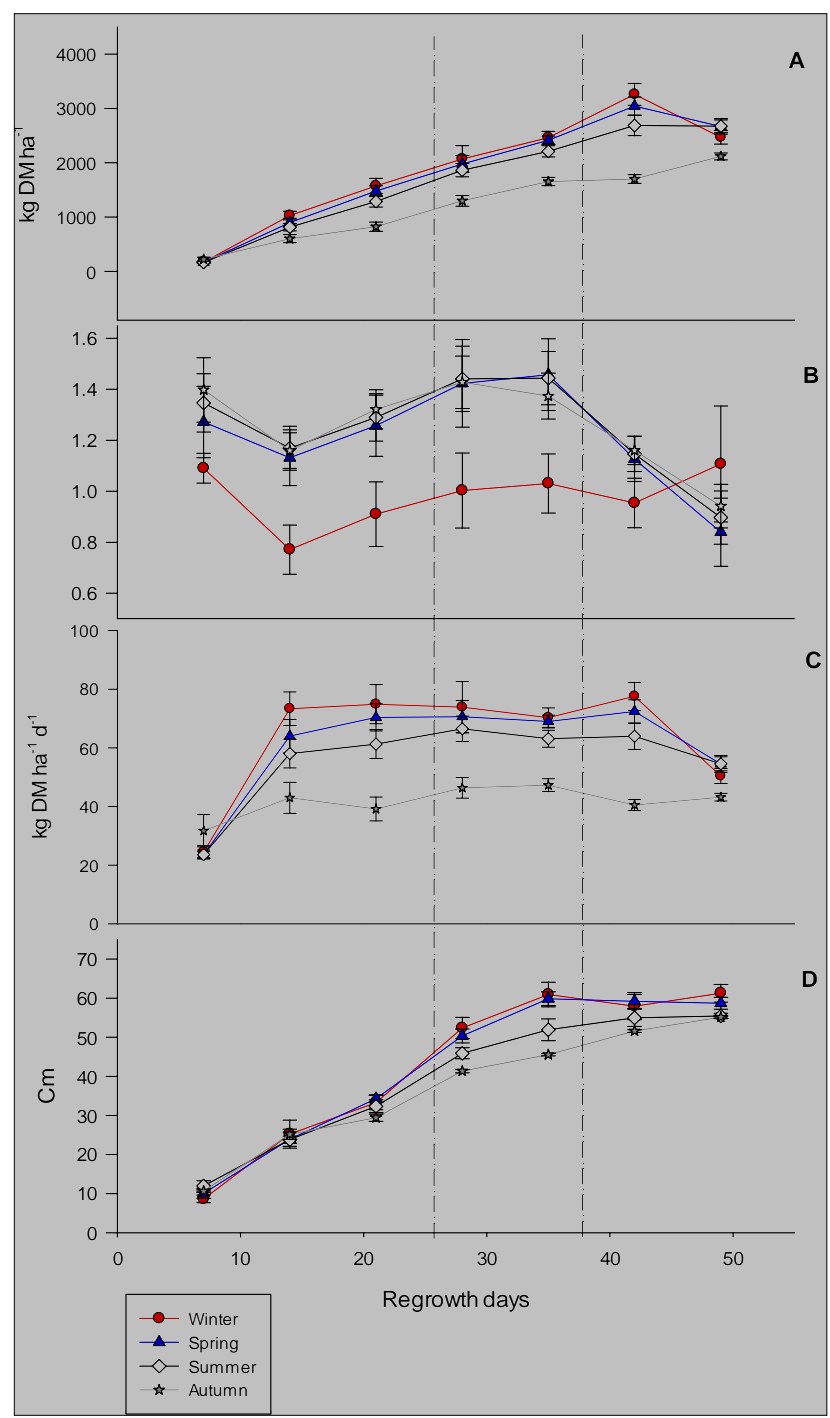


durante el día y de 10 a $20^{\circ} \mathrm{C}$ en la noche. El decremento en el rendimiento a la semana 7 en todas las épocas del año puede deberse a que la planta entra a su fase reproductiva, y conforme avanza la madurez, la senescencia se incrementa en la población total de plantas. Pero esta pérdida en el rendimiento puede ser compensada por otros componentes de la pradera como la relación tamaño - densidad(27).

Con respecto a la altura de la planta (Cuadro 1) en la época de primavera e invierno no se registraron diferencias $(P>0.05)$ después de los días 35 días de rebrote ( 56 a $60 \mathrm{~cm}$ y 58 a 61 $\mathrm{cm}$, respectivamente); en el verano en los días 42 y 49 días ( 49.5 a $54.7 \mathrm{~cm}$ ); y solo en otoño se registró mayor altura $(\mathrm{P}<0.01)$ hasta la accumulation occurred on d 28, 35 and 42 , respectively.

Differences in results may be due to temperature in the winter, as during those months the average temperature fluctuated between 19 and $21{ }^{\circ} \mathrm{C}$ while in other studies the presence of frost affected the net lucerne accumulation $(1,12,16)$. According to what was reported in the literature(26), the optimum temperature for lucerne growth is of 15 to $25^{\circ} \mathrm{C}$ during the day and 10 to $20^{\circ} \mathrm{C}$ at night. Yield decrement at wk 7 all times of the year may be because the plant enters its reproductive phase, and with maturity, senescence is increased in the total population of plants. But this yield loss can be

Cuadro 1 Rendimiento de forraje, tasa de crecimiento, altura de forraje y relación hoja:tallo en praderas de alfalfa criolla sometidas a ciclos de crecimiento de 7 semanas

Table 1. Forage yield, growth rate, forage height and leaf: stem ratio in native lucerne grasslands subjected to growth cycles of $7 \mathrm{wk}$

\begin{tabular}{|c|c|c|c|c|c|c|c|c|c|}
\hline \multirow[b]{2}{*}{ Season } & \multicolumn{7}{|c|}{ Regrowth days } & \multirow[b]{2}{*}{ SE } & \multirow[b]{2}{*}{$P$} \\
\hline & 7 & 14 & 21 & 28 & 35 & 42 & 49 & & \\
\hline \multicolumn{10}{|c|}{ Yield (kg DM ha-1) } \\
\hline Spring & $166 \mathrm{~d}$ & $696 \mathrm{~cd}$ & $1265 \mathrm{cb}$ & 1722 b & $2396 \mathrm{a}$ & $2668 \mathrm{a}$ & $2794 a$ & 175 & ** \\
\hline Summer & $164 d$ & $645 \mathrm{~cd}$ & $903 \mathrm{c}$ & $1630 \mathrm{~b}$ & $1799 \mathrm{~b}$ & 1972 b & $2680 a$ & 161 & ** \\
\hline Autumn & $222 \mathrm{f}$ & $602 \mathrm{e}$ & $822 \mathrm{~d}$ & $1298 \mathrm{c}$ & $1654 \mathrm{~b}$ & $1700 \mathrm{~b}$ & $2116 a$ & 64 & ** \\
\hline Winter & $165 \mathrm{e}$ & $1096 d$ & $1692 \mathrm{~cd}$ & 2234 bc & $2432 b$ & 3416 a & $2544 b$ & 201 & ** \\
\hline \multicolumn{10}{|c|}{ Height (cm) } \\
\hline Spring & $11.5 \mathrm{e}$ & $22.6 \mathrm{~d}$ & $35.3 c$ & $48.3 \mathrm{~b}$ & $56.1 \mathrm{a}$ & $58.8 \mathrm{a}$ & $60.4 \mathrm{a}$ & 1.3 & ** \\
\hline Summer & $12.4 \mathrm{~d}$ & $24.9 c$ & $29.4 \mathrm{C}$ & $43.5 b$ & $45 \mathrm{~b}$ & $49.5 \mathrm{ab}$ & $54.7 \mathrm{a}$ & 1.9 & ** \\
\hline Autumn & $10.7 \mathrm{~g}$ & $25.2 f$ & $29.4 \mathrm{e}$ & $41.3 \mathrm{~d}$ & $45.5 \mathrm{c}$ & $51.6 \mathrm{~b}$ & $55.1 \mathrm{a}$ & 0.7 & ** \\
\hline Winter & $8.6 \mathrm{e}$ & $25.2 d$ & $33.3 \mathrm{c}$ & $52.4 \mathrm{~b}$ & $60.9 \mathrm{a}$ & $58 a b$ & $61.2 \mathrm{a}$ & 2.4 & ** \\
\hline \multicolumn{10}{|c|}{ Growth rate $\left(\mathrm{kg} \mathrm{DM} \mathrm{ha}^{-1} \mathrm{~d}^{-1}\right)$} \\
\hline Spring & $23 \mathrm{c}$ & $50 \mathrm{~b}$ & $60 a b$ & $62 a b$ & $68 \mathrm{a}$ & $64 \mathrm{ab}$ & $57 \mathrm{ab}$ & 5 & ** \\
\hline Summer & $23 \mathrm{~b}$ & $46 \mathrm{a}$ & $43 a$ & $58 \mathrm{a}$ & $51 \mathrm{a}$ & $47 \mathrm{a}$ & $55 \mathrm{a}$ & 5.5 & ** \\
\hline Autumn & $31 \mathrm{~b}$ & $43 a b$ & $39 a b$ & $46 \mathrm{a}$ & $47 \mathrm{a}$ & $40 a b$ & $43 a b$ & 3.9 & * \\
\hline Winter & $24 \mathrm{C}$ & $78 \mathrm{a}$ & $81 \mathrm{a}$ & $80 \mathrm{a}$ & $70 a b$ & $81 \mathrm{a}$ & $52 \mathrm{~b}$ & 6.5 & ** \\
\hline \multicolumn{10}{|c|}{ Leaf:stem ratio } \\
\hline Spring & $1.4 \mathrm{a}$ & $1.3 \mathrm{a}$ & $1.5 \mathrm{a}$ & $1.7 \mathrm{a}$ & $1.7 \mathrm{a}$ & $1.3 a b$ & $0.7 \mathrm{~b}$ & 0.19 & ** \\
\hline Summer & $1.6 \mathrm{a}$ & $1.3 a b$ & $1.4 \mathrm{ab}$ & $1.5 \mathrm{a}$ & $1.4 \mathrm{ab}$ & $1.2 \mathrm{ab}$ & $1.1 \mathrm{~b}$ & 0.11 & ** \\
\hline Autumn & $1.6 \mathrm{a}$ & $1.1 \mathrm{a}$ & $1.4 \mathrm{a}$ & $1.4 \mathrm{a}$ & $1.1 \mathrm{a}$ & $1.2 \mathrm{a}$ & $1.1 \mathrm{a}$ & 0.26 & ** \\
\hline Winter & $1.1 \mathrm{a}$ & $0.7 \mathrm{a}$ & $0.8 \mathrm{a}$ & $0.8 \mathrm{a}$ & $0.9 \mathrm{a}$ & $0.8 \mathrm{a}$ & $1.1 \mathrm{a}$ & 0.17 & ** \\
\hline
\end{tabular}

abcd Means with the same letters in each row are not different. SE = standard error.

${ }^{*}(P<0.05) ;{ }^{* *}(P<0.01)$. 
semana $7(55 \mathrm{~cm})$. En la Figura 1D, se puede observar que a excepción de invierno y primavera, a partir de los 28 días de crecimiento, verano y otoño registraron las menores alturas $(\mathrm{P}<0.05)$. La altura de la pradera es una variable altamente correlacionada con el rendimiento de materia seca(20), si los coeficientes de correlación son elevados ( $>0.80$ ); esta variable puede ser considerada para determinar el rendimiento y definir el momento óptimo de aprovechamiento. En este experimento en las cuatro épocas del año se registraron $r^{2}$ superiores a 0.8 (Figura 2), lo que indica que los parámetros obtenidos son aceptables y similares a los de otras investigaciones $(19,20)$. Otros autores(14) reportaron que en alfalfa en invernadero, y bajo fertiriego, los mayores rendimientos coincidieron con los valores superiores de altura de forraje. También se menciona que la altura del forraje solo varía en el primer año de establecimiento del cultivo(28), pero a partir del segundo año, las alturas no son significativas $(P>0.05)$, por lo que independientemente de la variedad, la alfalfa presenta alturas similares; sin embargo la temperatura sí influye en el rendimiento y la altura por época del año.

La tasa de crecimiento del cultivo (TC) es un aproximado de qué tanta biomasa vegetal se acumula en el tiempo después de la defoliación. La edad a la cual alcanzaron la mayor TC varió dependiendo de la época del año (Cuadro 1), y los valores obtenidos registraron que las mayores TC fueron en el invierno, a los 21, 28

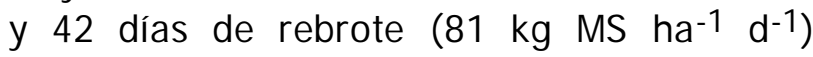
$(P<0.05)$; en primavera no se registró diferencia desde los 21 a los 57 días de crecimiento; sin embargo, el mayor registro fue a la semana 5 (68 kg); en verano el mayor valor fue al día 28

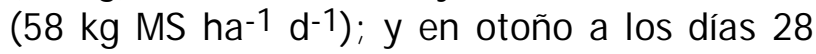
y $35(47 \mathrm{~kg})$. A excepción del otoño $(P<0.05)$ no se registraron diferencias entre días de corte en la TC, solo en invierno a la semana 1 presentó la menor TC, pero posteriormente en las semanas 2 a la 6 , fue superior a las demás estaciones del año (Figura 1C). Estos valores compensated by other components of the pastureland as the relationship size: density(27).

With respect to the plant height (Table 1 ) during spring and winter there were no differences after $35 \mathrm{~d}$ of regrowth (56 to $60 \mathrm{~cm}$ and 58 to

Figura 2. Regresiones lineales del rendimiento vs altura, intervalo de confianza al 95, y la predicción de los datos, en las cuatro épocas del año

Figure 2. Linear regressions of the yield vs height, confidence interval at 95, and prediction of the data, in the four seasons of the year

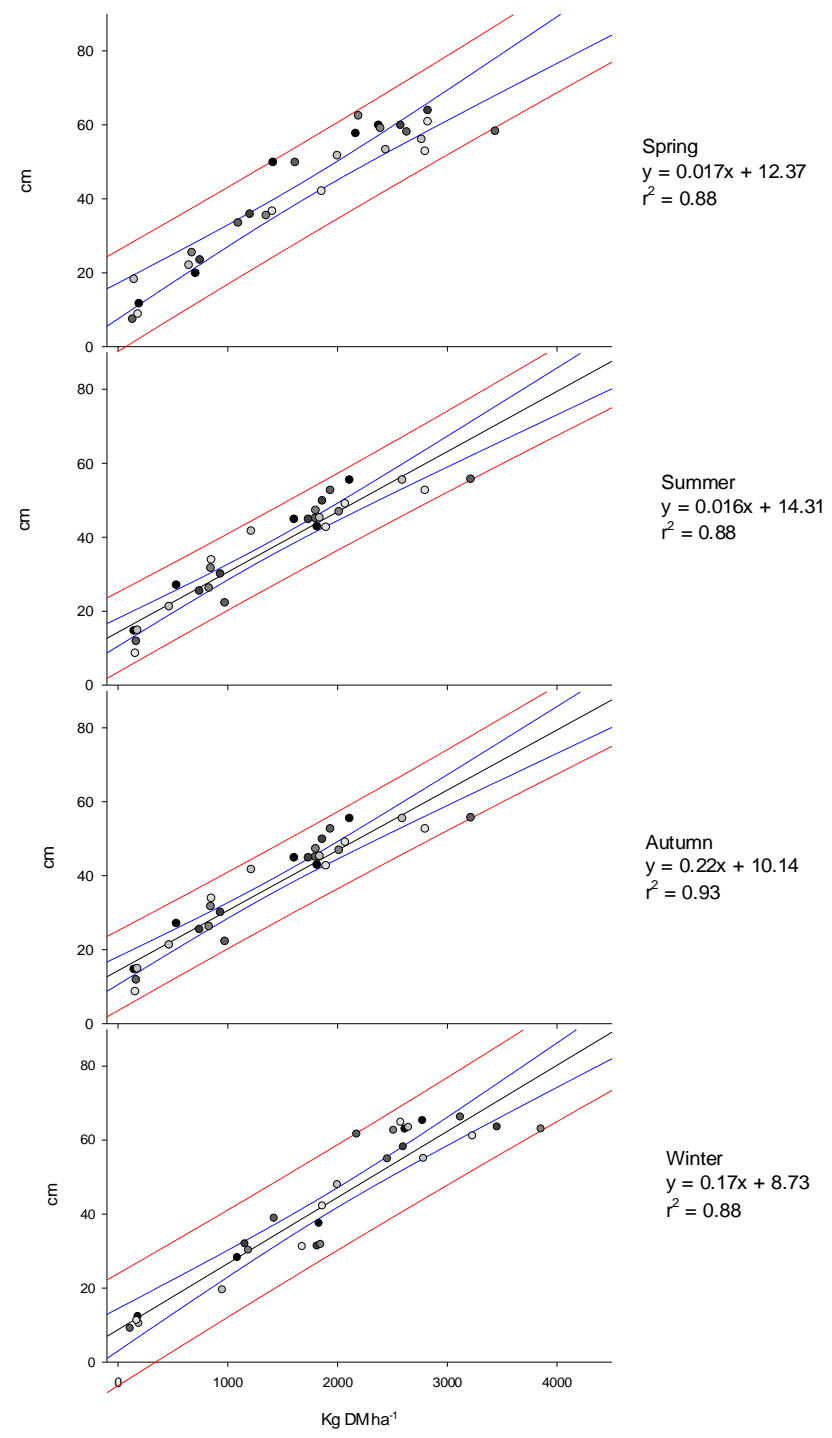

Slope of the line (black line), confidence interval (blue line), prediction of the data (red line). 
son similares a los observados en otra investigación(10), en la misma variedad de alfalfa de un año de establecida, ya que registraron que las mayores TC en primavera fueron entre los días 28 y 35, mientras que en invierno solo coincide a la sexta semana de rebrote. $Y$ difieren a los resultados en otras investigaciones $(25,29)$, donde afirman que los menores valores de TC se registraron en invierno, a diferencia de este trabajo; sin embargo, en ambos estudios(25,29) la presencia de heladas propició una menor tasa de crecimiento, a diferencia del presente estudio donde no se registraron heladas en invierno (Figura 3).

La relación hoja:tallo es la variable más correlacionada con la calidad nutritiva del forraje, y en este experimento se registró que a excepción del invierno $(P<0.05)$, no existieron diferencias en las otras épocas (Figura 1B). Solo en primavera y verano se presentaron diferencias entre los días de rebrote $(P<0.01)$, siendo los días 28 y 35 que registraron el mayor valor (1.7 y 1.5, respectivamente). En otoño la
$61 \mathrm{~cm}$, respectively); in the summer on $\mathrm{d} 42$ and 49 (49.5 to $54.7 \mathrm{~cm})$; and only in autumn was recorded a higher height $(P<0.01)$ until wk $7(55 \mathrm{~cm})$. Figure 1D, shows that with the exception of winter and spring, after $28 \mathrm{~d}$ of regrowth summer and autumn recorded lower heights $(P<0.05)$. Forage height is a variable that is highly correlated with dry matter yield(20), if the correlation coefficients are high $(>0.80)$, this variable can be considered to determine the yield and define the optimum harvesting time. In this experiment in the four seasons of the year the $r^{2}$ were higher than 0.8 (Figure 2), which indicates that the parameters obtained are acceptable and similar to other researchs $(19,20)$. Other authors(14) reported that with lucerne in greenhouse and under fertigation conditions, the highest yields coincided with higher values of forage height. Other studies(28) mention that the heights of the forage varies only in the first year of establishment of the crop, but from the second year onwards, the heights are not significant $(P>0.05)$, so regardless of the variety, the lucerne presents

Figura 3. Datos climáticos durante el periodo experimental. Fuente: Estación meteorológica del aeropuerto Benito Juárez, de la ciudad de Oaxaca

Figure 3. Climate data during the experimental period. Source: Meteorological station of the Benito Juárez airport, of the Oaxaca city

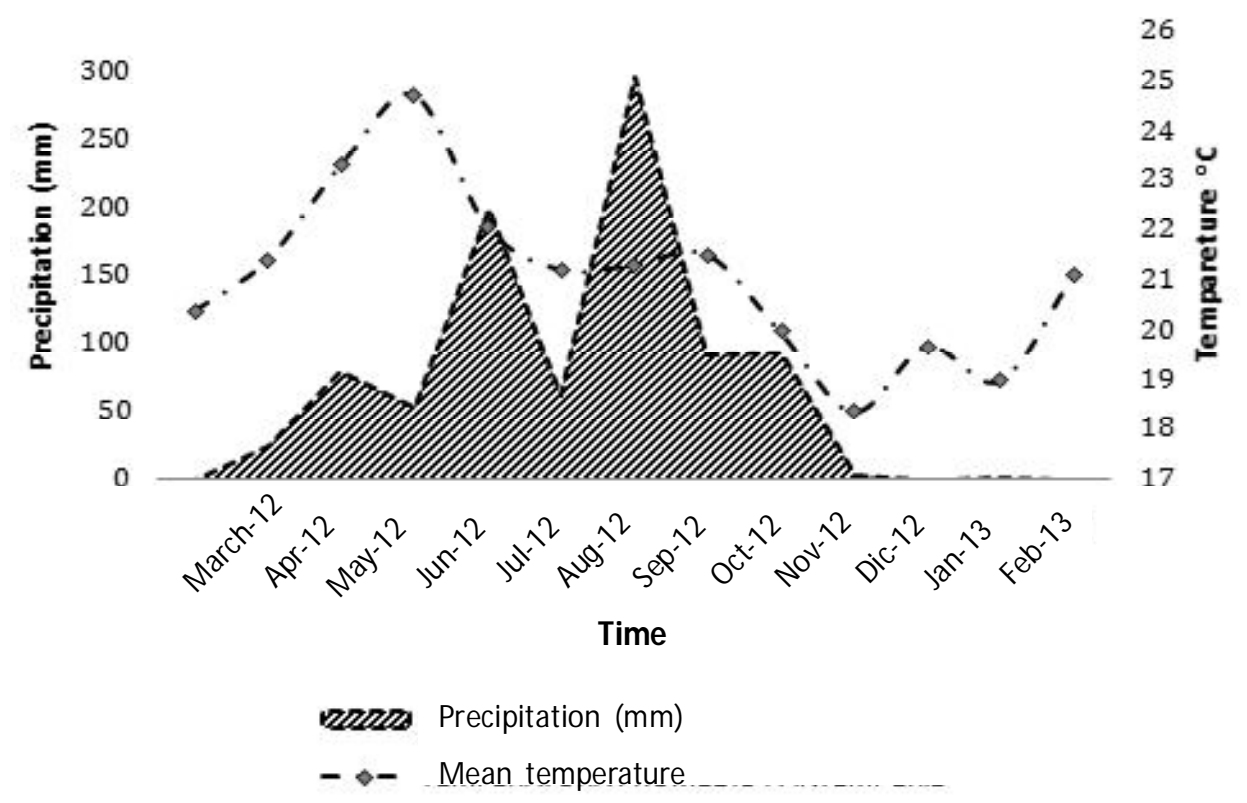


mejor relación hoja: tallo fue al día 28 y en el invierno al 35 (Cuadro 1). Rivas et al(13) mencionan que la menor relación se presenta en las variedades de alfalfa que producen el mayor rendimiento de materia seca, y corrobora la importancia que tienen las variables del tallo (peso y altura) en relación a las hojas, para la acumulación de materia seca total y la calidad o valor nutritivo en la planta; es decir, que a mayor altura menor proporción de hoja, y esto está relacionado con la fase de crecimiento del forraje. Otros trabajos(6) mencionan que la cantidad de proteína en las hojas y en el tallo, es afectada por la edad del cultivo, pero no influye en el contenido de fibra cruda y materia seca, por lo tanto, el corte debe definirse por una combinación de variables de la especie que se esté evaluando. Otros autores(9), mencionan que la aparición de hojas primarias es mayor cuando la alfalfa está en su fase de rebrote, en la fase reproductiva o destinada a la producción de semilla, y esto repercute en la intercepción de luz, y la acumulación de biomasa en raíz, y por lo tanto en el rendimiento total de biomasa y la calidad nutritiva del forraje.

Los resultados obtenidos difieren a lo reportado en la misma variedad de alfalfa(10) y en la misma zona, que explican que la menor relación hoja: tallo presentó el siguiente orden descendente otoño > verano > invierno > primavera, y que indistintamente de la estación del año la relación tendió a disminuir conforme aumentaba la semana de rebrote. De la misma forma se ha reportado(25) que la mayor relación hoja:tallo se presentó en otoño e invierno. En otra investigación(30) se observó una disminución progresiva en la relación hoja:tallo conforme aumentó la edad de rebrote de la alfalfa, registrando la mayor acumulación de forraje a la quinta semana en verano, otoño y primavera mientras que en invierno fue a la sexta semana. Estas diferencias se debieron a que en el presente estudio las condiciones de temperatura presentes en invierno propiciaron una mayor acumulación de materia seca y el desarrollo de tallos más altos (Figura 1D), lo que incrementó su aporte al rendimiento; esto aunado a un similar heights; however the temperature influences yield and height by time of year.

The growth rate is an approximation of plant biomass accumulation in time after defoliation. The age at which lucerne reached the highest GR varied depending on the time of year (Table 1 ), and the higher GR values recorded were in the winter, at 21,28 and $42 \mathrm{~d}$ of regrowth (81 kg DM ha-1 $\left.\mathrm{d}^{-1}\right)(\mathrm{P}<0.05)$; in the spring there was not a difference from 21 to $57 \mathrm{~d}$ of growth; however, the greatest record was at 5 wk (68 $\mathrm{kg}$ ); in summer the highest value was at $\mathrm{d} 28$ (58 kg DM ha-1 $\mathrm{d}^{-1}$ ); and in the fall to 28 and $35 \mathrm{~d}(47 \mathrm{~kg})$. With the exception of the fall $(P<0.05)$ there were not reported differences among days of cutting in the GR, just in winter at wk 1 presented the lower GR, but subsequently in wk 2 to 6 , it was superior to the other seasons of the year (Figure 1C). These values are similar to those observed in another study (10), with the same lucerne variety from a year of established; the higher GR was in spring between d 28 and 35, while in winter only matched by the 6 th $w k$ of regrowth. These results differ to results from other studies $(25,29)$, where report lower GR values in winter, unlike this work; however, in both studies $(25,29)$ the presence of frost led to a lower growth rate, unlike the present study where there were no frost in winter (Figure 3).

The leaf:stem ratio is the variable most correlated with the nutritious forage quality, and in this experiment that was so, in that except for the winter $(P<0.05)$, there were no differences at other times (Figure 1B). Differences between regrowth days were only in spring and summer $(P<0.01)$, being the $d 28$ and 35 which recorded the greatest value (1.7 and 1.5 , respectively). In autumn the best value was at $\mathrm{d} 28$ and in winter to d 35 (Table 1). Rivas et al(13) mention that the lowest ratio occurs in lucerne varieties that produce the greatest dry matter yield, and corroborates the importance of the variables stem (height and weight) in relation to the leaves, for the accumulation of total dry matter and the quality 
recambio de tejido más rápido, como se pudo observar en las mayores tasas de crecimiento presentes en esta época (Figura 1C), propició la presencia de material senescente, y la pérdida de hojas por dicho proceso ocasionó que la relación hoja:tallo (Figura 1B) fuera menor que en las demás estaciones.

Con respecto a la composición botánica (Figura 4), los componentes registraron una variación en su aporte en las épocas del año; el mayor aporte de alfalfa se registró en invierno y otoño, y la mayor presencia de otros pastos y malezas fue en primavera y verano. En las épocas de invierno y verano el mayor aporte de alfalfa fue or nutrition in the plant; i.e. that the higher height the lower leaf proportion, and this is related to the growth phase of the forage. Other works(6) mentioned that the amount of protein in the leaves and stem, is affected by age of the crop, but it has no influence on the content of dry matter and crude fiber; therefore, the cut must be defined by a combination of variables of the species assessed. Other authors $(9)$, mention that the emergence of primary leaves is increased when lucerne is in their regrowth stage, during reproduction or destined to the production of seed, and this has repercussions on the interception of light, biomass root accumulation, and therefore in

Figura 4. Composición botánica de alfalfa criolla, en ciclos de crecimiento de 7 semanas, en las diferentes épocas del año

Figure 4. Botanical composition of native lucerne, in cycles of growth of $7 \mathrm{wk}$, at different times of the year

SPRING
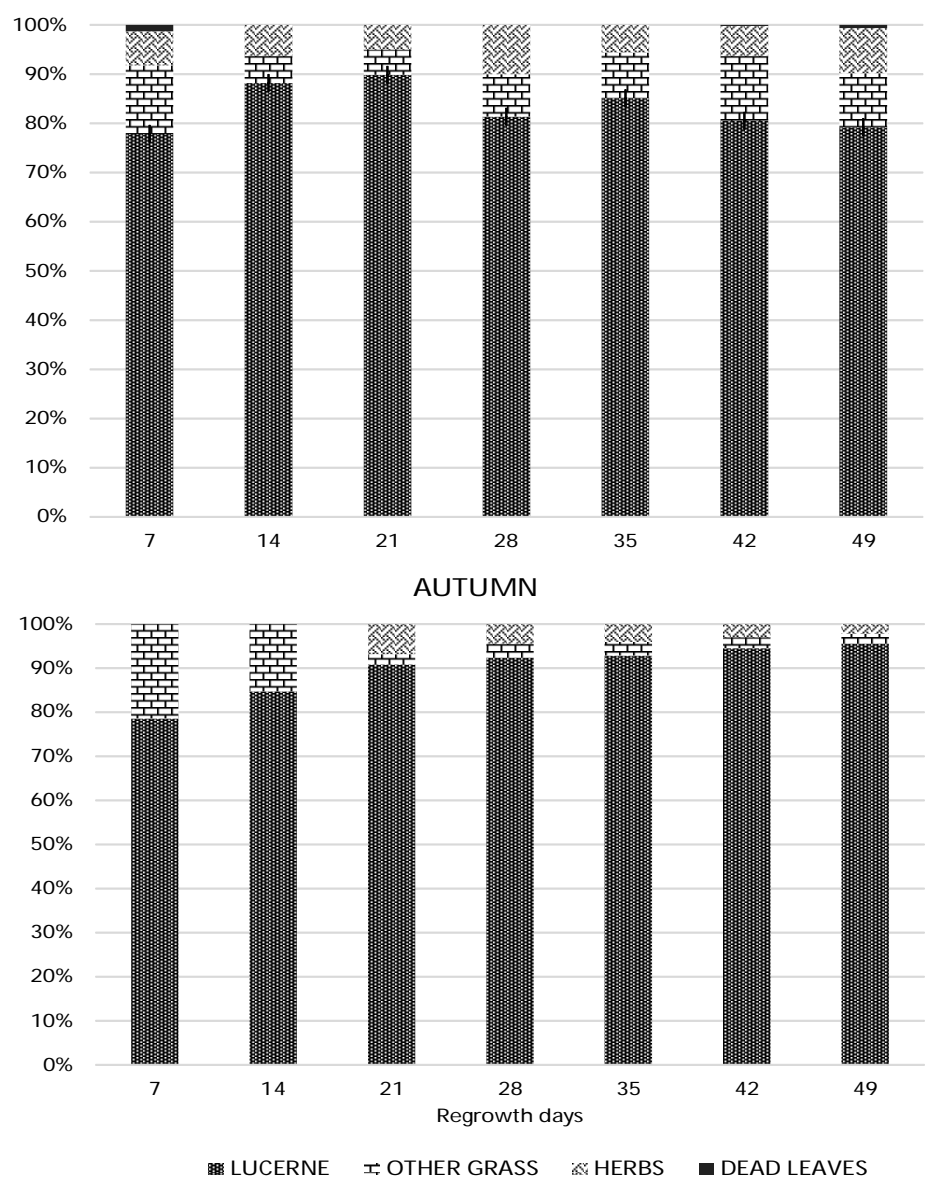

SUMMER

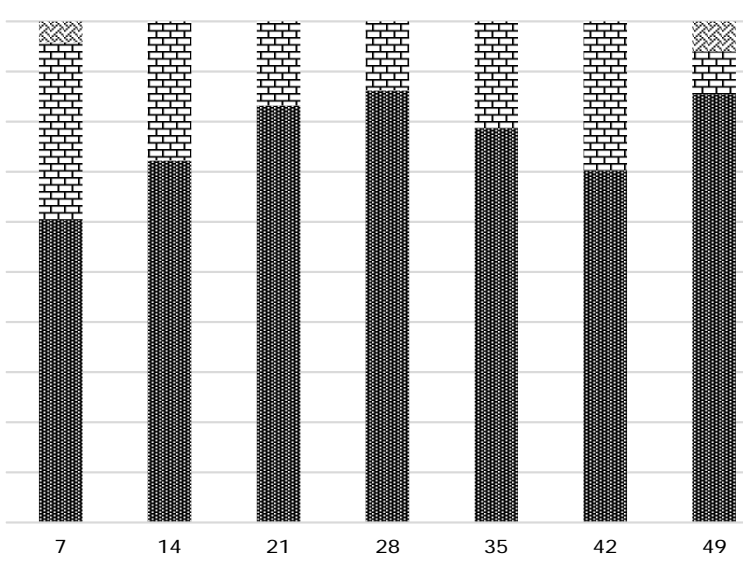

WINTER

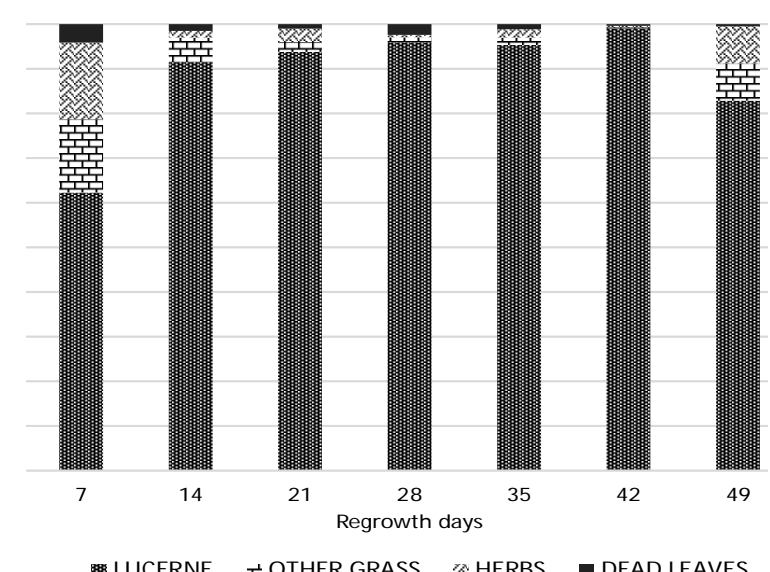


a los 28 días de crecimiento, en primavera a los 21 y 35, y en el otoño hasta el día 49 (Figura 3). Estos resultados concuerdan con lo reportado en otro trabajo(25), que en primavera y verano hubo mayor presencia de malezas; también se ha reportado(29) que las estaciones de otoño y verano fueron las que registraron el menor y mayor porcentaje de malezas, mientras que en primavera hubo un incremento en el porcentaje de malezas y una reducción en alfalfa(1). Esto concuerda con el aumento de la precipitación pluvial en ambas épocas, que junto a la temperatura, propiciaron la aparición de otras especies de pastos que entraron en competencia con la alfalfa.

Se concluye que para el cultivo de alfalfa Var. Oaxaca criolla, en la Villa de Zaachila, se recomienda realizar cortes cada 30 a 35 días en invierno y primavera, y cada 35 a 40 en verano y otoño, para obtener los mayores rendimientos de forraje y mejor relación hoja:tallo. Realizar cortes con base a la dinámica de crecimiento, considerando las variables de tasa de crecimiento, relación hoja:tallo, composición botánica y altura, permiten determinar el momento óptimo de defoliación para obtener el mejor contenido de hoja con respecto al tallo, mejor altura y menor proporción de material muerto, lo que permite obtener un forraje de mejor calidad. Las dinámicas de crecimiento determinan el comportamiento fenológico del cultivo en las diferentes épocas del año, el cual varía dependiendo de las condiciones ambientales que se presenten.

\section{LITERATURA CITADA}

1. Mendoza PSI, Hernández GA, Pérez PJ, Quero CAR, Escalante EAS, Zaragoza RJL, Ramírez RO. Respuesta productiva de la alfalfa a diferentes frecuencias de corte. Rev Mex Cienc Pecu 2010; 1(3):287-296.

2. Cangiano CA, Pece MA. Acumulación de biomasa aérea en rebrotes de alfalfa en Balcarce. Rev Arg Prod Anim 2005; (25): 39-52.

3. Villegas AY, Hernández GA, Martínez HPA, Pérez PJ, Herrera HJG. López CC. Rendimiento de forraje de variedades de the total biomass yield and nutritive quality of the forage.

The obtained results differ to those reported with the same lucerne variety and in the same area(10), explaining that the lowest leaf:stem ratio presented the following descending order: autumn $>$ summer $>$ winter $>$ spring, and that regardless of the season of the year, the relationship tended to decrease as the week of regrowth increased. In the same way it has been reported(25) that greater leaf:stem ratio was presented in autumn and winter. A progressive decrease in the ratio was observed in another study(30) in which as regrowth age of lucerne increased, registered greater forage accumulation at the 5th wk in summer, autumn and spring while in winter it was at the 6th wk. These differences could be explained because in the present study the temperature conditions in winter led to a greater dry matter accumulation and the development of more tall stems (Figure 1D), which increased its yield contribution; this, coupled with a faster replacement tissue as it could be observed by greater growth rates in this period (Figure 1C), led to the presence of senescent material, and the loss of leaves by this process caused the leaf:stem ratio (Figure 1B) be lower than in the other seasons.

Regarding the botanical composition (Figure 4), components recorded a variation in their contribution according to the seasons of the year; the biggest contribution of lucerne was recorded in winter and autumn, and the increased presence of other grasses and weeds was in spring and summer. In the winter and summer seasons the biggest contribution of lucerne was at $28 \mathrm{~d}$ of growth, in spring at 21 and $35 \mathrm{~d}$, and in the fall until the $\mathrm{d} 49$ (Figure 3 ). These results agree with those reported elsewhere(25), which in spring and summer were increased presence of weeds; it has also been reported a greater percentage of weeds in autumn and lesser in summer seasons, while in spring there was an increase in the percentage of weeds and a reduction in 
alfalfa en dos calendarios de corte. Rev Fitotec Mex 2006; 29(4):369-372.

4. Hernández-Garay A, Matthew C, Hodgson, J. The influence of defoliation height on dry-matter partitioning and $\mathrm{CO}_{2}$ exchange of perennial ryegrass miniature sward. Grass Forage Sci 2000; (54):1-5.

5. Basigalup D. Mejoramiento de la calidad forrajera de la alfalfa. Rev Agromer 2000; (42):16-18.

6. Cupic T, Grljusic S, Popovic S, Stjepanovic M, Tucak $M$. Protein and fiber contents in alfalfa leaves and stems. In: Delgado I, Lloveras J editors. Quality in lucerne and medics for animal production. Zaragoza, Spain: ClHEAM;2001:215218

7. Martiniello P, Texeria da Silva JA. Physiological and bioagronomical aspect involved in growth and yield components of cultivated forage species in Mediterranean environments: A review. Eur J Plant Sci Biot 2011;5(2):6498.

8. Teixeira EI, Moot DJ, Brown HE. Defoliation frequency and season affected radiation use efficiency and dry matter partitioning to roots of Lucerne (Medicago sativa L.) crops. Euro J Agr 2008;(28): 103-111.

9. Teixeira El, Brown HE, Meenken ED, Moot DJ. Growth and phenological development patterns after between seedling and regrowth lucerne crops (Medicago sativa L.). Euro J Agr 2011; (35)47-55.

10. Villegas AY, Hernández GA, Pérez PJ, López CC, Herrera HJG, Enríquez QJF, Gómez VA. Patrones estacionales de crecimiento de dos variedades de alfalfa (Medicago sativa L.). Téc Pecu Méx 2004;42(2): 145-158.

11. Velasco ZME, Hernández GA, González HVA. Cambios en componentes del rendimiento de una pradera de ballico perenne, en respuesta a la frecuencia de corte. Rev Fitotec Mex 2007;30(1): 79-87.

12. Dorantes, J. Respuesta productiva de tres variedades de alfalfa (Medicago sativa L.) a dos intensidades de pastoreo [tesis maestría]. Texcoco, Edo. de México: Colegio de Posgraduados; 2000.

13. Rivas JMA, López CC, Hernández GA, Pérez PJ. Efecto de tres regímenes de cosecha en el comportamiento productivo de cinco variedades comerciales de alfalfa (Medicago sativa L.). Téc Pecu Méx 2005;43(1):79-92.

14. Morales AJ , J iménez VJ L, Velasco WA, Villegas AY, Enríquez VJ R, Hernández GA. Evaluación de 14 variedades de alfalfa con fertirriego en la mixteca de Oaxaca. Téc Pecu Méx 2006; 44(3): 277-288.

15. Castro RR, Hernández GA, Vaquera HH, Hernández GJ, Quero CA, Enríquez QJ F, Martínez HPA. Comportamiento productivo de asociaciones de gramíneas con leguminosas en pastoreo. Rev Fitotec Mex 2012;35(1):87-95.

16. Hernández GA, Pérez PJ, Hernández JA. Crecimiento y rendimiento de la alfalfa en respuesta a diferentes regímenes de cosecha. Agrociencia 1992;(2):131-144.

17. INEGI. Mapa geoestadístico municipal, versión 3.1. http:// www3.inegi.org. $\mathrm{mx} / \mathrm{sistemas/mexicocifras/datos-geograficos/}$ 20/20565. pdf Consultado 30 Mar, 2015.

18. Crespo RJ, Castaño JA, Capurro JA. Secado del forraje con el horno de microondas: efecto sobre el análisis de calidad. Agric Téc 2007;67(2):210-218.

19. Castro RR, Hernández GA, Aguilar BG, Ramírez RO. 2011. Comparación de métodos para estimar rendimiento de forraje lucerne (29). This is consistent with the increase in rainfall in both times, which along with the temperature, led to the emergence of other grass species that came into competition with lucerne.

In conclusion, for the cultivation of lucerne Var. Creole Oaxaca, in the village of Zaachila, the best time for cutting is every 30 to $35 \mathrm{~d}$ in winter and spring, and every 35 to $40 \mathrm{~d}$ in summer and autumn, to obtain the highest forage yields and better leaf:stem ratio. Cutting should be based on the dynamics of growth, the growth rate, leaf:stem ratio, botanical composition and height variables, in order to obtain the optimum defoliation time for the best content of leaf with respect to stem, best height and lower proportion of dead material, which allows to obtain a better forage quality. The growth dynamics determine the phenological crop performance at different times of the year, which varies depending on the environmental conditions.

End of english version

en praderas asociadas. Naturaleza y Desarrollo 2011;9(1):3846.

20. Castillo EG, Valles MB, Jarillo RJ. Relación entre materia seca presente y altura en gramas nativas del trópico mexicano. Téc Pecu Méx 2009;47(1):79-92.

21. SigmaPlot. User's Guide (Version 12.0.). Systat software 2015.

22. SAS. User's Guide: Statistics (Version 9.0 ed.). Cary NC, USA: SAS Inst. Inc. 2002.

23. Wolfinger RD. Covariance structure selection in general mixed models. Communications in statistics simulation and computation. Philadelphia 1993;22(4):1079-1106.

24. Littell RC, Milliken GA; Stroup WW, Wolfinger RD. SAS System for mixed models. Cary: SAS Institute, 1996.

25. Rojas GA. Dinámica de crecimiento y rendimiento de forraje de diez variedades de alfalfa. [tesis maestría]. Texcoco, Edo. de México: Colegio de Posgraduados; 2011.

26. Muslera PE, Ratera CG. Praderas y forrajes, producción y aprovechamiento. 2a ed. Madrid, España: Ediciones MundiPrensa; 1991.

27. Brown HE, Moot DJ, Teixeira El. The components of lucerne (Medicago sativa) leaf area index respond to 
Fausto J avier Montes Cruz, et al. / Rev Mex Cienc Pecu 2016; 7(4):539-552

temperature and photoperiod in a temperate environment. Euro J Agr 2005; 23:348-358.

28. Altinok S, Karakaya A. Forage yield of different alfalfa cultivars under Ankara Conditions. Turk J Agric For 2002; (26):11-16.

29. Cadena VS. Dinámica de crecimiento y rendimiento de alfalfa (Medicago sativa L.) en respuesta a diferentes frecuencias de cosecha [tesis maestría]. Edo. de México: Colegio de Posgraduados; 2009.

30. Zaragoza EJ, Hernández GA, Pérez PJ, Herrera HJG, Osnaya GF, Martínez HPA, et al. Análisis de crecimiento estacional de una pradera asociada alfalfa-pasto ovillo. Téc Pecu Méx 2009; 47(2): 173-188. 